\title{
Peranan Mikroorganisme Endofit Dalam Dunia Kesehatan: Kajian Pustaka
}

\author{
Rina Hidayati Pratiwi \\ e-mail: rina.hp2012@gmail.com \\ Program Studi Pendidikan Biologi, Fakultas Matematika dan Ilmu Pengetahuan Alam \\ Universitas Indraprasta PGRI
}

\begin{abstract}
The infection disease is still important problem in Indonesia, especially in eastern part of Indonesia. The problem of the bacterial resistance has resulted in increased morbidity, mortality, and costs of healthcare. This situation is therefore drives many researches on discovery for new antibiotics and novel bioactive compounds to combat multidrug resistant microbes, such as Mycobacterium tuberculosis, Staphylococcus spp., and Streptococcus spp. The aim of this study is to know the development of the endophytic microorganisms. The endophytic bacteria provide vast potential in producing various novel natural products, including secondary metabolites similar to their hosts. The plant is one of host for the endophytic microorganisms reside. In Indonesia, that endophytic is used medicinally for treatment as well as from the host. The bioactive compound of endophytic microorganisms are used medicinally for treatment antibacterial, antiviral, anticancer, antioxidants, antidiabetic, and immunosuppressive. These showed that endophytic bacteria are promising source of new antibiotics against susceptible and resistant forms of various infectious microbes.
\end{abstract}

Keywords: bioactive, compound, endophytic, plant, medicinally

\begin{abstract}
ABSTRAK
Penyakit infeksi masih menjadi masalah di Indonesia, khususnya di bagian timur Indonesia, Masalah resistensi bakteri terhadap antibiotik berdampak terhadap meningkatnya angka morbiditas, mortalitas, dan perawatan kesehatan. Keadaan ini yang membuat banyak peneliti melakukan pencarian terhadap senyawa bioaktif baru sebagai alternatif kandidat antibiotik untuk melawan bakteri multidrug resisten seperti Mycobacterium tuberculosis, Staphylococcus spp., dan Streptococcus spp. Studi ini bertujuan mengetahui perkembangan mikroorganisme endofit sehingga kita dapat mengetahui peranan mikroorganisme endofit dalam dunia kesehatan. Bakteri endofit menyediakan potensi yang besar untuk menghasilkan berbagai senyawa bioaktif yang baru yang diperoleh dari senyawa metabolit sekunder dari inangnya. Tanaman merupakan salah satu inang untuk mikroorganisme endofit. Senyawa bioaktif dari mikroorganisme endofit digunakan secara luas di dunia kesehatan sebagai antibakteri, antivirus, antikanker, antioksidan, antidiabetes, dan anti immunosupresif. Hal tersebut menunjukkan bahwa bakteri endofit dapat menjadi sumber antibiotik baru yang menjanjikan untuk mengatasi masalah resistensi bakteri patogen dan penyakit di dunia kesehatan.
\end{abstract}

Kata Kunci: bioaktif, endofit, kesehatan, senyawa, tanaman 


\section{PENDAHULUAN}

Kebutuhan akan senyawa baru yang potensial untuk menyelesaikan permasalahan di berbagai bidang khususnya bidang kesehatan adalah suatu hal yang sangat penting. Oleh karena itu pencarian senyawa yang memiliki potensi untuk mengatasi penyakit infeksi pada manusia masih terus dilakukan. Ketahanan terhadap antibiotik yang terjadi pada bakteri, penyisipan virus dan meningkatnya infeksi fungi pada populasi manusia di dunia merupakan masalah kesehatan yang cukup serius.

Kebutuhan senyawa antibiotik baru, agen kemoterapi, dan agrokimia dengan persyaratan memiliki efektivitas tinggi, toksisitas yang rendah serta memiliki dampak lingkungan yang kecil masih sangat dibutuhkan. Pentingnya pencarian senyawa ini juga disebabkan berkembangnya ketahanan mikroorganisme penyebab infeksi (seperti spesies Staphylococcus, Mycobacterium, dan Streptococcus) terhadap senyawa-senyawa bioaktif yang sudah ada dan oleh karena adanya mikroorganisme yang resisten secara alami. Masalah kesehatan lainnya ialah masalah immunocompromised (yang terjadi pada penderita kanker dan pasien transplantasi organ) sangat beresiko terhadap patogen-patogen opportunistik seperti Aspergillus spp., Cryptococcus spp., dan Candida spp. yang sebenarnya secara normal tidak menjadi masalah pada manusia karena secara alami mikroorganisme tersebut berperan sebagai flora normal pada tubuh manusia.

Produk senyawa-senyawa di alam secara alami diperoleh dari mikroorganisme, tanaman, dan atau hewan. Produk senyawa dari alam tersebut sudah dieksploitasi untuk kebutuhan manusia selama ribuan tahun dan telah menjadi sumber utama dari senyawa-senyawa untuk bahan baku obat. Pengguna terbesar obat-obatan tradisional ialah negara Cina dengan lebih kurang 5000 tanaman dan produk-produk tanaman dalam pharmacopoeia (Bensky \& Gamble 1993).

Istilah endofit berasal dari kata endon yang berarti di dalam dan phyton yang berarti tanaman. Penggunaan istilah ini memiliki arti secara luas dan secara harfiah bahwa endofit itu dihuni oleh organisme yang potensial seperti bakteri (Kobayashi \& Palumbo 2000), fungi (Stone et al. 2000), tanaman (Marler et al. 1999), insekta dalam tanaman (Feller 1995), serta untuk alga di dalam alga (Peters 1991).

Istilah endofit sebagai contohnya digunakan untuk alga endofit patogen (Bouarab et al. 1999), tanaman endofit parasit (Marler et al. 1999), bakteri endofit mutualistik (Bai et al. 2002), fungi endofit mutualistik (Schulz \& Boyle 2005), bakteri dan fungi patogen dalam fase perkembangan laten (Sinclair \& Cerkauskas 1996), serta untuk mikroorganisme dalam simbiosis komensalistik (Sturz \& Nowak 2000).

Bakteri termasuk kelompok sel prokariotik dan fungi termasuk eukariotik, namun mereka saling memberikan perangkat dalam asosiasinya dengan tanaman inang dan keduanya saling mengkolonisasi jaringan di akar secara sistemik interseluler dan intraseluler. Mereka berbeda dalam model kolonisasinya, seperti bakteri utamanya mengkolonisasi secara interseluler meskipun mereka juga ditemukan secara intraseluler seperti Azoarcus spp. (Hurek et al. 1994). Mikroorganisme tersebut ditemukan di dalam jaringan vaskuler pada inang tanaman (Kobayashi \& Palumbo 2000). Kolonisasi asimptomatik oleh fungi bisa secara interseluler dan intraseluler di sepanjang akar. Kolonisasi pada fungi seringkali berasosiasi dengan patogenisitasnya (Schulz \& Boyle 2005). 
Aspirin (asam salisilat) merupakan salah satu contoh obat yang berasal dari bahan-bahan alami yaitu salicin glikosida. Salicin glikosida ditemukan pada spesies tanaman dari genus Salix dan Populus. Sebenarnya masih banyak orang yang belum mengetahui akan kegunaan dari masingmasing organ tanaman seperti akar, batang, dan daun. Dahulu orang melakukan pencampuran ketiga organ tersebut untuk pengobatan yang dapat membantu mengurangi rasa sakit dan penderitaan akibat adanya infeksi penyakit. Meskipun demikian, mereka sebenarnya belum mengetahui secara kimia senyawa bioaktif alami dalam kompleks pencampuran organ tersebut dan belum bisa menjawab bagaimana mereka bisa bermanfaat untuk pengobatan. Tujuan dari studi ini ialah mengetahui karakteristik serta manfaat dari mikroba endofit dan senyawanya.

\section{METODE}

Metode penelitian yang digunakan adalah kajian kepustakaan dengan pendekatan deskriptif berdasarkan pustaka sekunder dari artikel-artikel penelitian. Penelusuran pustaka digali melalui situs google (www.google.co.id) dan google scholar (www.scholar.google.co.id) dengan kata kunci terkait seperti bakteri endofit, khamir endofit, kapang endofit, antibiotik, dan sebagainya.

\section{PEMBAHASAN}

\section{Teknik Isolasi dan Koleksi Endofit}

Mula-mula sampel tanaman diseleksi, kemudian diambil bagian organ tanamannya seperti akar, batang, dan daun. Batang dari tanaman dipotong dan dimasukkan ke dalam wadah plastik yang diberi seal. Uap air yang muncul dihilangkan dan dijaga kelembabannya, lalu disimpan pada suhu $4{ }^{\circ} \mathrm{C}$ sampai diperlakukan di laboratorium. Saat di laboratorium semua sampel dari organ tanaman dicuci dengan menggunakan $70 \%$ etanol, disterilisasi dengan cara didekatkan api untuk kemudian dikeringanginkan di dalam laminar air flow cabinet. Hal tersebut dilakukan untuk mengeliminasi mikroba yang ada di permukaan tanaman. Selanjutnya dengan menggunakan pisau steril, jaringan terluar dihilangkan dari sampel dan jaringan dalam secara hati-hati dipotong lalu ditempatkan di atas agar cawan. Beberapa hari setelah diinkubasi, ujung-ujung hifa fungi dipotong dan dipindahkan ke medium PDA. Bakteri juga muncul dari jaringan tanaman termasuk Streptomyces spp. Jika kita menginginkan kemurnian dari mikroba endofit, maka mikroba endofit diuji kemampuannya untuk tumbuh dalam kultur yang diguncang atau tetap dengan menggunakan berbagai medium dan kondisi pertumbuhan yang bervariasi, termasuk $15 \%$ gliserol pada suhu $-70{ }^{\circ} \mathrm{C}$. Jika kondisi pertumbuhannya cocok maka mikroba dapat difermentasi dan diekstrak serta senyawa bioaktifnya dapat diisolasi dan dikarakterisasi.

\section{Produk Mikroba Endofit untuk Mengatasi Bakteri Patogen}

Mikroorganisme endofit dapat menghasilkan produk senyawa yang dapat melawan bakteri patogen, senyawa tersebut disebut antibiotik. Antibiotik didefinisikan sebagai senyawa organik alami dengan berat molekul rendah yang memiliki kemampuan untuk melawan atau membunuh mikroorganisme patogen pada konsentrasi yang paling kecil (Demain 1981). Mikroba endofit ini sebagai sumber senyawa antibiotik, yaitu senyawa alami yang dapat menghambat atau membunuh mikroorganisme berbahaya, patogen atau yang dapat menyebabkan penyakit. Penyakit tersebut 
tidak hanya pada manusia tetapi juga pada hewan dan tumbuhan.

Cryptosporiopsis quercina adalah tahapan tidak sempurna dari Pezicula cinnamomea, suatu fungi yang berasosiasi dengan spesies tumbuhan berkayu di Eropa. Fungi tersebut merupakan mikroba endofit dari tanaman Tripterigeum wilfordii, yang merupakan tanaman obat asli dari Eurasia. Cryptosporiopsis quercina menunjukkan aktivitas anti fungi melawan beberapa fungi patogen manusia seperti Candida albicans dan Trichophyton spp, penyebab penyakit kulit dan kuku. Selain itu senyawa dari $C$. quercina juga menunjukkan aktivitas penghambatan terhadap fungi patogen pada tanaman, seperti Sclerotinia sclerotiorum dan Botrytis cinerea. Senyawa yang terkandung pada $C$. quercina ialah cryptocandin yaitu suatu antimikotik peptida yang unik (Strobel et al. 1999), seperti echinocandins dan pneumocandins (Walsh 1992). Selain itu senyawa cryptocandin juga mengandung sejumlah asam amino peculiar hydroxylated dan asam amino baru yaitu 3-hydroxy-4-hydroxy methyl proline. Cryptocin, adalah suatu asam tetramik unik yang dihasilkan oleh $C$. quercina. Senyawa Cryptocin memiliki potensi dalam menghambat mikroorganisme Pyricularia oryzae yang merupakan fungi patogen tanaman (Li et al. 2000).

Senyawa Ecomycin potensial dalam melawan fungi patogen manusia, seperti Cryptococcus neoformans dan Candida albicans. Senyawa tersebut dihasilkan oleh bakteri endofit Pseudomonas viridiflava, dimana bakteri tersebut merupakan salah satu anggota dari kelompok bakteri fluorescent yang berasosiasi dengan daun tanaman dari kelompok rumput-rumputan. Bakteri Pseudomonas viridiflava ditemukan pada atau di dalam jaringan tumbuhan (Miller et al. 1998). Senyawa Ecomycin termasuk ke dalam kelompok lipopeptida baru yang memiliki berat molekul 1,153 dan 1,181. Senyawa tersebut mengandung asam amino alanin, serin, treonin, dan glisin serta asam amino lain seperti homoserin dan $\beta$-hydroxyaspartic acid.

$$
\text { Pseudomycins merupakan }
$$

kelompok lipopeptida yang aktif menghambat berbagai fungi patogen pada manusia seperti $C$. albicans, $C$. neoformans, dan fungi patogen pada tumbuhan, seperti Ceratocystis ulmi dan Mycosphaerella fijiensis serta sejumlah fungi ascomycetous. Senyawa antifungi Pseudomycins dihasilkan oleh bakteri kelompok pseudomonad yang berasosiasi dengan tanaman (Ballio et al. 1994). Pseudomycins mengandung berbagai asam amino seperti L-chlorothreonine, Lhydroxy aspartic acid, serta D- dan Ldiaminobutyric acid. Molekul-molekul tersebut adalah alternatif untuk digunakan sebagai obat pada manusia setelah dimodifikasi strukturnya untuk menghilangkan toksisitas pada mamalia.

Pestalotiopsis microspora adalah mikroba endofit yang umum pada hutan hujan tropis. Mikroorganisme endofit tersebut juga dapat diisolasi dari tumbuhan langka Torreya taxifolia. $P$. microspora dapat menghasilkan berbagai senyawa yang memiliki aktivitas antifungal seperti pestalosida yaitu $\beta$ glucosida aromatik dan 2 pyrone: pestalopyrone dan hydroxypestalopyrone (Lee et al. 1995). Senyawa-senyawa ini juga menghasilkan fitotoksik. Pestalotiopsis microspora dari $T$. brevifolia menghasilkan 2 senyawa baru caryophyllene sesquiterpenes yaitu pestalotiopsins A dan B (Pulici et al. 1996) serta sesquiterpenes lain yaitu $2-\alpha-$ hydroxydimeninol dan highly functionalized humulane (Pulici et al. 1996). Senyawa yang dihasilkan oleh fungi endofit bervariasi tergantung dari kondisi kultural dari mikrobanya dan sumber tanaman inangnya. Pestalotiopsis jesteri yang 
merupakan mikroba endofit dari tanaman di sekitar sungai Sepik di Papua New Guinea, dapat menghasilkan jesterone dan hydroxy-jesterone. Senyawasenyawa tersebut dapat menghambat aktivitas antifungi melawan berbagai fungi patogen tanaman ( $\mathrm{Li} \&$ Strobel 2001).

Phomopsichalasin, merupakan senyawa metabolit dari mikroba endofit Phomopsis sp. Phomopsichalasin menunjukkan senyawa tipe cytochalasin dengan sistem 3 cincin yang menempatkan cincin cytochalasin macrolide. Senyawa metabolit tersebut menunjukkan aktivitas antibakteri melawan bakteri Bacillus subtilis, Salmonella enterica serovar Gallinarum, dan Staphylococcus aureus. Selain itu menghasilkan aktivitas moderate melawan khamir Candida tropicalis (Horn et al. 1995).

Fusarium endofit dari tanaman Selaginella pallescens, yang tumbuh di daerah konservasi Guanacaste Costa Rica memiliki aktivitas yang potensial antifungi melawan $C$. albicans. Bahan antifungal pentaketide baru tersebut, CR377, diisolasi dari kultur cair fungi (Brady \& Clardy 2000).

Asam colletotric adalah senyawa metabolit dari Colletotrichum gloeosporioides, yaitu fungi endofit dari tanaman Artemisia mongolica. Asam colletotric menunjukkan aktivitas antimikroba melawan bakteri dan fungi Helminthsporium sativum. Selain Colletotrichum sp., yang diisolasi dari tanaman herba tradisional Cina yaitu Artemisia annua (Lu et al. 2000). Sama seperti pada tanaman Artemisia anпиа yang menghasilkan senyawa antimalaria, beberapa endofit dari tanaman tersebut juga menunjukkan aktivitas anti protozoa.

Antibiotik dengan spektrum luas dihasilkan oleh Streptomyces sp. strain NRRL 30562. Streptomyces sp. strain NRRL 30562 merupakan mikroorganisme endofit pada tanaman $K$. nigriscans. Senyawa antibiotik yang dihasilkannya disebut munumbicins. Secara umum munumbicins menunjukkan aktivitas yang dapat menghambat bakteri Gram positif seperti Bacillus anthracis, Mycobacterium tuberculosis serta bakteri lainnya yang resisten terhadap antibiotik. Munumbicins D juga diketahui dapat menghambat parasit penyebab malaria yaitu Plasmodium falciparum, yang memiliki daya hambat $50 \%$ pada konsentrasi $4.5 \pm 0.07 \mathrm{ng} / \mathrm{ml}$ (Castillo et al. 2002). Aktinomisetes tidak hanya diperoleh dari tanah namun juga lebih kurang 30\%, aktinomisetes terdapat pada tumbuhan. Banyak dari aktinomisetes endofit tersebut yang menghasilkan antibiotik.

Streptomyces endofit lainnya ialah Streptomyces sp. strain NRRL 30566 dari pohon Grevillea (Grevillea pteridifolia) yang tumbuh di Northern Territory di Australia. Streptomyces tersebut menghasilkan antibiotik baru yang bernama kakadumycins. Tiap antibiotik ini mengandung asam amino alanine, serine, dan asam amino yang belum diketahui. Kakadumycin A memiliki aktivitas antibiotik spektrum luas sama dengan munumbicin $\mathrm{D}$, khususnya dalam menghambat bakteri Gram positif. Secara umum, senyawa tersebut memperlihatkan aktivitas yang lebih baik dibandingkan echinomycin. Kakadumycin A memiliki nilai MIC terhadap B. anthracis sebesar 0,2-0,3 $\mu \mathrm{g} /$ $\mathrm{ml}$, sedangkan echinomycin memiliki nilai MIC sebesar 1,0-1,2 $\mu \mathrm{g} / \mathrm{ml}$. Kedua senyawa tersebut sama-sama memiliki aktivitas yang lebih baik dalam menghambat $P$. falciparum dengan $50 \%$ dosis letal dalam kisaran 7-10 ng/ ml (Castillo et al. 2003). Kedua senyawa tersebut membuktikan bahwa di dalam aktinomisetes endofit mengandung senyawa antibiotik yang cukup menjanjikan dalam dunia kesehatan. 
Muscodor albus adalah fungi endofit yang diperoleh dari dahan atau ranting-ranting cabang pohon Cinnamomum zeylanicum (Cinnamon) (Worapong et al. 2001). Fungi Xylariaceaous (produksi non spora) secara efektif dapat menghambat dan membunuh bakteri tertentu serta fungi dengan cara memproduksi suatu campuran senyawa volatil (Strobel et al. 2001). Campuran senyawa volatil yang memiliki sifat antibiotik dihasilkan oleh fungi. Setiap 5 kelas senyawa volatil yang dihasilkan oleh fungi memiliki beberapa efek penghambatan terhadap fungi dan bakteri uji, namun tidak ada yang bersifat letal. Bagaimanapun, senyawa tersebut bertindak secara sinergis untuk menyebabkan kematian dalam kisaran luas terhadap fungi dan bakteri patogen manusia dan hewan. Senyawa penghambat yang paling efektif ialah dari kelompok ester, dimana secara biologis isoamil asetat adalah senyawa yang paling aktif. Implikasi dan keuntungan secara Ekologi, ialah bahwa senyawa tersebut dapat digunakan untuk mikofumigasi pada tanah, biji-bijian, dan tanaman, serta digunakan untuk dekontaminasi limbah manusia. Mikofumigasi dengan menggunakan mikroba $M$. albus ini lebih baik karena dapat menggantikan mikofumigasi sebelumnya yang dianggap ilegal dengan menggunakan senyawa berbahaya metil bromida. Dengan adanya $M$. albus sebagai alat skrining, maka memungkinkan untuk mengisolasi fungi endofit lainnya yang menghasilkan antibiotik volatil.

$$
\text { Muscodor roseus adalah }
$$

mikroorganisme yang diperoleh dari spesies tumbuhan yang tumbuh di Northern Territory di Australia. Fungi tersebut efektif dalam menghambat dan mematikan mikroba uji di laboratorium sama seperti pada $M$. albus (Worapong et al. 2002). Spesies non muscodor, yaitu Gliocladium sp. dikenal sebagai produser antibiotik volatil, namun komponen volatil dari organisme tersebut berbeda dengan komponen volatil yang diperoleh dari $M$. albus atau $M$. roseus. Berdasarkan fakta yang ditemukan di alam, annulene ialah inhibitor volatil yang paling berlimpah, yaitu senyawa yang digunakan untuk bahan bakar roket dan ditemukan pertama kalinya sebagai produk alami dalam fungi endofit. Bioaktivitas senyawa volatil dari Gliocladium sp. tidak sama cakupannya dan tidak sebaik yang dari Muscodor spp. (Stinson et al. 2003).

\section{Produk Mikroba Endofit untuk Mengatasi Penyebaran Virus Virulen}

Penggunaan lainnya yang cukup penting dari senyawa atau produk antibiotik fungi endofit ialah penghambatan virus. Ada 2 inhibitor protease cytomegalovirus manusia yang baru, yaitu cytonic acids A dan B yang telah diisolasi dari fermentasi fungi endofit Cytonaema sp. Strukturstrukturnya sama seperti isomer-isomer p-tridepside yang dielusidasi dengan metode Mass Spectrometry dan NMR (Guo et al. 2000). Penemuan tersebut menunjukkan bahwa penemuan senyawasenyawa dari endofit yang memiliki aktivitas anti viral masih sangat potensial dalam perkembangannya.

\section{Produk Mikroba Endofit sebagai Bahan Antikanker}

Paclitaxel dan beberapa turunannya merupakan kelompok utama senyawa antikanker yang dihasilkan oleh endofit. Paclitaxel adalah diterpenoid fungsional yang ditemukan pada spesies tanaman cemara di dunia (Suffness 1995). Mode of action dari paclitaxel ialah menghasilkan molekul-molekul tubulin dari depolimerisasi selama proses pembelahan sel. Senyawa paclitaxel adalah obat antikanker pertama di dunia yang digunakan untuk perawatan penyakit proliferasi jaringan manusia. 
Ditemukannya senyawa paclitaxel dalam spesies pohon cemara membuat endofit menjadi bahan kajian yang perlu dipelajari lebih mendalam. Pada tahun 1990-an belum ada fungi endofit yang ditemukan pada tanaman cemara di dunia. Setelah dilakukan berbagai penelitian, diketahui bahwa fungi endofit $T$. andreanae, yang diisolasi dari tanaman $T$. brevifolia dapat menghasilkan senyawa paclitaxel baru (Strobel et al. 1993). Penelitian selanjutnya diperoleh ada beberapa endofit yang umum ditemukan dari tanaman cemara yaitu dari kelompok Pestalotiopsis spp.

Salah satu dari spesies mikroba endofit yang paling umum diisolasi dari tanaman Taxus wallichiana ialah $P$. microspora. Mikroba tersebut dapat menghasilkan paclitaxel (Strobel et al. 1996). Beberapa mikroorganisme langka lainnya yang diketahui hampir punah seperti Wollemi pine (Wollemia nobilis), Pestalotiopsis guepini juga diketahui dapat menghasilkan paclitaxel (Strobel et al. 1997). Berbeda halnya dengan spesies tanaman dari kelompok Rubiaceous yaitu Maguireothamnus speciosus. Tanaman tersebut mengandung fungi endofit baru, yaitu Seimatoantlerium tepuiense, yang juga menghasilkan paclitaxel. Selain itu yang dapat memproduksi paclitaxel fungal ialah fungi endofit Periconia sp. dan Seimatoantlerium nepalense.

Mikroba yang paling sensitif dengan senyawa paclitaxel adalah patogen tanaman seperti Pythium spp. dan Phytophthora spp. Sensitivitasnya terhadap paclitaxel berdasarkan interaksinya dengan tubulin, sama halnya dengan caranya pada sel-sel kanker manusia (Schiff \& Horowitz 1980). Sebenarnya secara alami, mikroba endofit menghasilkan paclitaxel karena untuk melindungi tanaman inangnya dari degradasi dan penyakit yang disebabkan oleh patogen.
Senyawa paclitaxel juga dihasilkan oleh Tubercularia sp. yang diisolasi dari pohon cemara Cina di Selatan (Taxus mairei) di provinsi Fujian, Cina Utara Selatan (Wang et al. 2000). Sedikitnya 3 endofit dari tanaman $T$. wallichiana menghasilkan paclitaxel termasuk Sporormia minima dan Trichothecium sp. serta Corylus avellana cv. Gasaway (filbert).

Asam torreyanic, adalah suatu dimer kuinon sitotoksik selektif (bahan antikanker) yang diisolasi dari strain $P$. microspora. Strain bakteri ini merupakan endofit dari tanaman langka T. taxifolia (Florida torreya) (Lee et al. 1996). Setelah diuji dengan sel kanker, ternyata asam torreyanic menunjukkan 5 sampai 10 kali lebih sensitif terhadap protein kinase $\mathrm{C}$ agonist dan menimbulkan kematian sel oleh apoptosis. Aplikasi yang digunakan untuk mengetahui sintesis dari asam torreyanic, ialah biomimetic oxidation-dimerization cascade (Li et al. 2003).

Alkaloid secara umum juga dihasilkan oleh fungi endofit, diantaranya dari Genus Xylaria, Phoma, Hypoxylon, dan Chalara. Genus fungi tersebut sebagai penghasil senyawa cytochalasins. Senyawa-senyawanya berpotensi sebagai antitumor dan antibiotik, namun karena memiliki sifat toksisitas maka tidak digunakan sebagai bahan farmasi. Senyawa baru cytochalasins juga dihasilkan oleh Rhinocladiella sp. yang merupakan endofit dari tanaman Tripterygium wilfordii. Senyawasenyawa tersebut memiliki aktivitas anti tumor dan diidentifikasi sebagai 22-oxa[12]-cytochalasins (Wagenaar et al. 2000). Cytochalasin biasanya berasosiasi dengan fungi xylariaceaous dan belum pernah ditemukan satu atau lebih cytochalasins di fungi endofit. 


\section{Produk dari Mikroba Endofit sebagai Bahan Antioksidan \\ $P$. microspora merupakan endofit dari tanaman combretaceaous,} Terminalia morobensis, yang tumbuh di saluran air sungai Sepik Papua New Guinea (Harper et al. 2003). Diketahui ada 2 senyawa yang diperoleh dari kultur cair $P$. microspora, yaitu pestacin dan isopestacin. Pestacin dan isopestacin menunjukkan aktivitas antimikroba dan antioksidan. Aktivitas antioksidan isopestacin berdasarkan kesamaan strukturnya dengan flavonoid. Senyawa pestacin dan isopestacin mampu mencaricari superoksida dan radikal bebas hidroksil dalam suatu larutan (Strobel et al. 2002). Pestacin digambarkan dari cairan kultur yang sama, karena terjadi secara alami sebagai campuran racemic dan juga dapat memproses aktivitas antioksidan yang potensial. Aktivitas antioksidan pestacin meningkat terutama melalui pembelahan reaktif rantai $\mathrm{C}-\mathrm{H}$ yang tidak biasa dan untuk perluasan melalui pemisahan atau pemindahan $\mathrm{O}-\mathrm{H}$ (Strobel 2002). Aktivitas antioksidan pestacin 1 kali lebih baik dan lebih besar aktivitasnya dibanding trolox, yang merupakan derivat dari vitamin $\mathrm{E}$ (Harper et al. 2003).

\section{Produk dari Mikroba Endofit untuk Bahan Antidiabetes}

Senyawa metabolit fungi non peptida (L-783,281) adalah hasil isolasi dari fungi endofit (Pseudomassaria sp.) yang dikoleksi dari hutan hujan Afrika dekat Kinshasa di Republik Demokratik Kongo. Senyawa tersebut bertindak sebagai suatu insulin mimetic dan unlike insulin, kemungkinan diberikan secara oral namun tidak rusak dalam saluran pencernaan. Pemberian secara oral dari L-783,281 ke dua tikus percobaan yang menderita diabetes menghasilkan tingkat glukosa darah yang lebih rendah secara signifikan. Hasil-hasil tersebut bisa dijadikan sebagai terapi baru untuk diabetes (Zhang et al. 1999).

\section{Produk dari Mikroba Endofit sebagai Bahan Imunosupresif}

Obat-obatan imunosupresif saat ini digunakan untuk mencegah allograft rejection dalam proses transplantasi dan ke depannya obat tersebut dapat digunakan untuk mengobati penyakit autoimmune seperti rheumatoid arthritis dan diabetes yang kekurangan hormon insulin. Fungi endofitik Fusarium subglutinans, diisolasi dari T. wilfordii untuk menghasilkan senyawa immunosuppresive diterpene pyrones subglutinol A dan B yang bersifat non sitotoksik. Subglutinol A dan B samasama potensial dalam reaksi assay limfosit campuran dan thymocyte proliferation assay, dengan konsentrasi penghambatan sebesar 50\% dari $0,1 \mu \mathrm{M}$. Dalam sistem assay yang sama, obat siklosporin immunosuppressant yang telah dikenal sebelumnya potensial dalam reaksi limfosit campuran assay dan $10^{4}$ lebih potensial daripada thymocyte proliferation assay (Lee et al. 1995).

Pendekatan-pendekatan tersebut menghasilkan penemuan fungi Tolypocladium inflatum dari siklosporin, salah satu immunosuppressant yang potensial untuk diisolasi (Borel \& Kis 1991). Contoh-contoh dan hasil-hasil penemuan yang ada menggambarkan tujuan yang dilakukan oleh banyak peneliti saat ini, yaitu melakukan pencarian endofit yang langka dari inang dan lingkungan pada kondisi lingkungan ekstrim.

\section{KESIMPULAN}

Berdasarkan paparan di atas disimpulkan bahwa mikroorganisme endofit merupakan mikroorganisme yang hidup di dalam tanaman inang sebagai habitatnya. Mikroorganisme endofit bisa berupa bakteri, fungi, dan alga. Tanaman 
inang dari mikroorganisme endofit biasanya berupa tanaman obat dan tanaman yang statusnya hampir punah. Mikroorganisme endofit dapat berperan sebagai pengganti tanaman inang untuk menghasilkan senyawa bioaktif. Senyawa bioaktif yang ditemukan di mikroorganisme endofit berperan penting dalam bidang kesehatan sebagai antibiotik, antifungi, antikanker, antioksidan, antivirus, antidiabetes, serta bahan imunosupresif.

\section{DAFTAR PUSTAKA}

Bai, Y., Aoust, F., Smith, D., \& Driscoll, B. (2002). Isolation of plantgrowth-promoting Bacillus strains from soybean root nodules. Can $J$ Microbiol, 48, 230-238.

Ballio, A., Bossa, F., DiGiogio, P., Ferranti, P., Paci, M., Pucci, P., Scaloni, A., Segre, A., \& Strobel, G.A. (1994). Structure of the pseudomycins, new lipodepsipeptides produced by Pseudomonas syringae MSU $16 \mathrm{H}$. FEBS Lett., 355, 96-100.

Bensky, D., \& Gamble, A. (1993). Chinese herbal medicine. Materia medica, new ed. Eastland Press Inc., Seattle, Wash.

Bouarab, K., Potin, P., Correa, J., \& Kloareg, B. (1999). Sulfated oligosaccharides mediate the interaction between a marine red alga and its green algal pathogenic endophyte. Plant Cell, 11, 16351650.

Brady, S.F., \& Clardy, J. (2000). CR377, a new pentaketide antifungal agent isolated from an endophytic fungus. J. Nat. Prod., 63, 1447-1448.

Castillo, U., Harper, J.K., Strobel, G.A., Sears, J., Alexi, K., Ford, E., Lin, J., Hunter, M., Maranta, M., Ge, H., Yaver, D., Jensen, J.B., Porter, H., Robison, R., Millar, D., Hess,
W.M., Condron, M., \& Teplow, D. (2003). Kakadumycins, novel antibiotics from Streptomyces sp. NRRL 30566, an endophyte of Grevillea pteridifolia. FEMS Lett., 224, 183-190.

Castillo, U., Strobel, G.A., Ford, E.J., Hess, W.M., Porter, H., Jensen, J.B., Albert, H., Robison, R., Condron, M.A., Teplow, D.B., Stevens, D., \& Yaver, D. (2002). Munumbicins, wide-spectrum antibiotics produced by Streptomyces NRRL 30562, endophytic on Kennedia nigriscans. Microbiology, 148, 2675-2685.

Demain, A.L. (1981). Industrial Microbiology. Science, 214, 987994.

Feller, I.C. (1995). Effects of nutrient enrichment on growth and herbivory of dwarf red mangrove (Rhizophora mange). Ecol Monogr, 65, 477-505.

Guo, B., Dai, J., Ng, S., Huang, Y., Leong, C., Ong, W., \& Carte, B.K. (2000). Cytonic acids A and B: novel tridepside inhibitors of hCMV protease from the endophytic fungus Cytonaema species. J. Nat. Prod., 63, 602-604.

Harper, J.K., Ford, E.J., Strobel, G.A., Arif, A., Grant, D.M., Porco, J., Tomer, D.P., \& Oneill, K. (2003). Pestacin: a 1,3-dihydro isobenzofuran from Pestalotiopsis microspora possessing antioxidant and antimycotic activities. Tetrahedron, 59, 24712476.

Horn, W.S., Simmonds, M.S.J., Schwartz, R.E., \& Blaney, W.M. (1995). Phomopsichalasin, a novel antimicrobial agent from an endophytic Phomopsis sp. Tetrahed ron, 14, 3969-3978.

Hurek, T., Reinhold-Hurek, B., Van Montagu, M., \& Kellenberger, E. (1994). Root colonization and 
systemic spreading of Azoarcus sp. strain BH72 in grasses. J Bacteriol, 176, 1913-1923.

Kobayashi, D.Y., \& Palumbo, J.D. (2000). Bacterial endophytes and their effects on plants and uses in agriculture. In: Bacon CW, White JF (eds) Microbial endophytes. Dekker, New York.

Lee, J., Lobkovsky, E., Pliam, N.B., Strobel, G.A., \& Clardy, J. (1995). Subglutinols A and B: immunosuppressive compounds from the endophytic fungus Fusarium subglutinans. J. Org. Chem., 60, 7076-7077.

Lee, J., Strobel, C.G.A., Lobkovsky, E., \& Clardy, J.C. (1996). Torreyanic acid: a selectively cytotoxic quinone dimer from the endophytic fungus Pestalotiopsis

microspora.J. Org. Chem., 61, 3232-3233.

Lee, J.C., Yang, X., Schwartz, M., Strobel, G., \& Clardy, J. (1995). The relationship between an endangered North American tree and an endophytic fungus. Chem. Biol., 2, 721-727.

Li, C., Johnson, R.P., \& Porco, J.A. (2003). Total synthesis of the quinine epoxide dimer (+)torreyanic acid: application of a biomimetic

oxidation/electrocyclization/DielsAlder dimerization cascade. J. Am. Chem. Soc., 125, 5059-5106.

Li, J.Y., \& Strobel, G.A. (2001). Jesterone and hydroxy-jesterone antioomycetcyclohexenenone epoxides from the endophytic fungus Pestalotiopsis jesteri. Phytochemistry, 57, 261265.

Li, J.Y., Strobel, G.A., Harper, J.K., Lobkovsky, E., \& Clardy, J. (2000). Cryptocin, a potent tetramic acid antimycotic from the endophytic fungus Cryptosporiopsis $c f$. quercina. Org. Lett., 2, 767-770.

Lu, H., Zou, W.X., Meng, J.C., Hu, J., \& Tan, R.X. (2000). New bioactive metabolites produced by Colletotrichum sp., an endophytic fungus in Artemisia annua. Plant Sci., 151, 67-73.

Marler, M., Pedersen, D., Mitchell, O.T., \& Callaway, R.M. (1999). A polymerase chain reaction method for detecting dwarf mistletoe infection in Douglas fir and western larch. Can J For Res., 29, 13171321.

Miller, R.V., Miller, C.M., GartonKinney, D., Redgrave, B., Sears, J., Condron, M., Teplow, D., \& Strobel, G.A. (1998). Ecomycins, unique antimycotics from Pseudomonas viridiflava. $J$. Appl. Microbiol., 84, 937-944.

Peters, A.F. (1991). Field and culture studies of Streblonema-Macrocystis new species Ectocarpales Phaeophyceae from Chile, a sexual endophyte of giant kelp. Phycologia, 30, 365-377.

Pulici, M., Sugawara, F., Koshino, H., Uzawa, J., Yoshida, S., Lobkovsky, E., \& Clardy, J. (1996). Pestalotiopsin-A and pestalotiopsin-B: new caryophyllenes from an endophytic fungus of Taxus brevifolia. J. Org. Chem., 61, 2122-2124.

Pulici, M., Sugawara, F., Koshino, H., Uzawa, J., Yoshida, S., Lobkovsky, E., \& Clardy, J. (1996). A new isodrimeninol

from Pestalotiopsis sp. $J . \quad$ Nat. Prod., 59, 47-48.

Schiff, P.B., \& Horowitz, S.B. (1980). Taxol stabilizes microtubules in mouse fibroblast cells. Proc. Natl. Acad. Sci. USA, 77, 1561-1565.

Schulz, B., \& Boyle, C. (2005). The endophytic continuum. Mycol Res. , 109, 661-687. 
Sinclair, J.B. \& Cerkauskas, R.F. (1996). Latent infection vs. endophytic colonisation by fungi. In: Redlin SC, Carris LM (eds) Endophytic fungi in grasses and woody plants. APS, St Paul, MN.

Stinson, M., Ezra, D., \& Strobel, G. (2003). An endophytic Gliocladium sp. of Eucryphia cordifoliaproducing selective volatile antimicrobial compounds. Plant Sci. , 165, 913922.

Stone, J.K., Bacon, C.W., \& White, J.F. (2000). An overview of endophytic microbes: endophytism defined. In: Bacon CW, White JF (eds) Microbial endophytes. Dekker, New York.

Strobel, G., Yang, X., Sears, J., Kramer, R., Sidhu, R.S., \& Hess, W.M. (1996). Taxol fromPestalotiopsis microspora, an endophytic fungus of Taxus

wallichiana. Microbiology, 142, 435-440.

Strobel, G.A. (2002). Microbial gifts from rain forests. Can. J. Plant Pathol. , 24, 14-20.

Strobel, G.A., Stierle, A., Stierle, D., \& Hess, W.M. (1993). Taxomyces andreanae a proposed new taxon for a bulbilliferous hyphomycete associated with Pacific yew. Mycotaxon, 47, 71-78.

Strobel, G.A., Dirksie, E., Sears, J., \& Markworth, C. (2001). Volatile antimicrobials from a novel endophytic

fungus. Microbiology, 147, 29432950.

Strobel, G.A., Ford, E., Worapong, J., Harper, J.K., Arif, A.M., Grant, D.M., Fung, P.C.W., \& Chan, K. (2002). Ispoestacin, an isobenzofuranone from Pestalotiopsis microspora, possessing antifungal and antioxidant activities. Phytochemistry, 60, 179183.

Strobel, G.A., Miller, R.V., Miller, C., Condron, M., Teplow, D.B., \& Hess, W.M. (1999). Cryptocandin, a potent antimycotic from the endophytic

fungus Cryptosporiopsis $c f$. quercina. Microbiology, 145, 19191926.

Strobel, G.A., Hess, W.M., Li, J.Y., Ford, E., Sears, J., Sidhu, R.S., \& Summerell, B. (1997). Pestalotiopsis guepinii, a taxol producing endophyte of the Wollemi Pine, Wollemia nobilis. Aust. J. Bot., 45, 10731082.

Sturz, A.V., \& Nowak, J. (2000). Endophytic communities of rhizobacteria and the strategies required to create yield enhancing associations with crops. Appl Soil Ecol. , 15, 183-190.

Suffness, M. (1995). Taxol, science and applications. CRC Press, Boca Raton, Fla.

Wagenaar, M., Corwin, J., Strobel, G.A., \& Clardy, J. (2000). Three new chytochalasins produced by an endophytic fungus in the genus Rhinocladiella. J. Nat. Prod. , 63, 1692-1695.

Walsh, T.A. (1992). Inhibitors of $\beta$ glucan synthesis. In J. A. Sutcliffe and N. H. Georgopapadakou (ed.), Emerging targets in antibacterial and antifungal chemotherapy. Chapman \& Hall, London, United Kingdom.

Wang, J., Li, G., Lu, H., Zheng, Z., Huang, Y., \& Su, W. (2000). Taxol from Tubercularia sp. strain TF5, an endophytic fungus of Taxus mairei. FEMS Microbiol. Lett., 193, 249-253.

Worapong, J., Strobel, G.A., Ford, E.J., Li, J.Y., Baird, G., \& Hess, W.M. (2001). Muscodor albusgen. 
et sp. nov., an endophyte from Cinnamomum zeylanicum. Mycotaxon, 79, 67-79.

Worapong, J., Strobel, G.A., Daisy, B., Castillo, U., Baird, G., \& Hess, W.M. (2002). Muscodor

roseus anna. nov. an endophyte from Grevillea

pteridifolia. Mycotaxon, 81, 463475.

Zhang, B., Salituro, G., Szalkowski, D., Li, Z., Zhang, Y., Royo, I., Vilella, D., Dez, M., Pelaez, F., Ruby, C., Kendall, R.L., Mao, X., Griffin, P., Calaycay, J., Zierath, J.R., Heck, J.V., Smith, R.G., \& Moller, D.E. (1999). Discovery of small molecule insulin mimetic with antidiabetic activity in mice. Science, 284, 974-981. 